\title{
Het belang van de Vlaamse Ruit vanuit economisch perspectief
}

Citation for published version (APA):

Vanhaverbeke, W. P. M. (1997). Het belang van de Vlaamse Ruit vanuit economisch perspectief. NIBOR, Netherlands Institute of Business Organization and Strategy Research. NIBOR Research Memorandum No. 03 https://doi.org/10.26481/umanib.1997003

Document status and date:

Published: 01/01/1997

DOI:

10.26481/umanib.1997003

Document Version:

Publisher's PDF, also known as Version of record

\section{Please check the document version of this publication:}

- A submitted manuscript is the version of the article upon submission and before peer-review. There can be important differences between the submitted version and the official published version of record.

People interested in the research are advised to contact the author for the final version of the publication, or visit the DOI to the publisher's website.

- The final author version and the galley proof are versions of the publication after peer review.

- The final published version features the final layout of the paper including the volume, issue and page numbers.

Link to publication

\footnotetext{
General rights rights.

- You may freely distribute the URL identifying the publication in the public portal. please follow below link for the End User Agreement:

www.umlib.nl/taverne-license

Take down policy

If you believe that this document breaches copyright please contact us at:

repository@maastrichtuniversity.nl

providing details and we will investigate your claim.
}

Copyright and moral rights for the publications made accessible in the public portal are retained by the authors and/or other copyright owners and it is a condition of accessing publications that users recognise and abide by the legal requirements associated with these

- Users may download and print one copy of any publication from the public portal for the purpose of private study or research.

- You may not further distribute the material or use it for any profit-making activity or commercial gain

If the publication is distributed under the terms of Article $25 \mathrm{fa}$ of the Dutch Copyright Act, indicated by the "Taverne" license above, 
Het belang van de Vlaamse Ruit vanuit economisch perspectief

W. Vanhaverbeke

NIBOR/RM/97/03

http://www.unimaas.nl/ document/fdewb.htm

J.E.Lit. code: $\mathrm{O} 18$

$n i b o r$

Netherlands Institute of

Business Organization

and Strategy Research

University of Maastricht

Faculty of Economics and Business Administration P.O. Box 616

6200 MD Maastricht

The Netherlands

Phone: ++31 43 - 3883805 
Fax : :+31 43-3258495 


\section{HET BELANG VAN DE VLAAMSE RUIT VANUIT ECONOMISCH PERSPECTIEF}

Dr. Wim Vanhaverbeke

NIBOR

ISRO - K.U.Leuven

Universiteit Maastricht

Celestijnenlaan 131

Postbus 616

3001 Heverlee

6200 MD Maastricht

Nederland

Januari 1997 


\section{Samenvatting}

In het Structuurplan Vlaanderen wordt uitgegaan van de notie "Vlaamse Ruit", die op termijn een stedelijk netwerk op internationaal niveau zou moeten worden. Concreet gaat het om de ruit Antwerpen, Gent, Brussel en Leuven. De Vlaamse Ruit bevat de grootstedelijke gebieden Brussel, Antwerpen en Gent, de regionaal stedelijke gebieden Leuven, Mechelen, Sint-Niklaas en Aalst, de structuurondersteunende kleinstedelijke gebieden Asse, Dendermonde, Lier en Lokeren (en Vilvoorde) en de kleinstedelijke gebieden op provinciaal niveau Beveren, Boom, Wetteren en Willebroek.

De vraag stelt zich of het wel economisch zinvol is om Vlaanderen - dat toch al niet zo groot is - verder op te splitsen in een Vlaamse Ruit en het gebied daarbuiten. Het antwoord hierop plaatsen we binnen het kader van de metamorfose van de Vlaamse economie van een industriële economie naar een kenniseconomie. Kennis wordt steeds belangrijker als economische succesfactor en Vlaanderen zal naast een moderne infrastructuur voor vervoer van goederen en personen ook een kennisinfrastructuur dienen uit te bouwen indien het een economisch sterke positie wil innemen gedurende de volgende decennia. Een goed functionerend grootstedelijk netwerk op internationaal niveau is hierbij onmisbaar. De potentieel economische groei van Vlaanderen zal ten dele bepaald worden door de mate waarin men slaagt om de Vlaamse Ruit op te waarderen tot een echt grootstedelijk netwerk met een internationale uitstraling.

Dit rapport is als volgt ingedeeld. In de volgende sectie wordt een begrippelijk kader geschetst waarbinnen het economisch belang van de Vlaamse Ruit kan geduid worden. In de derde sectie wordt ingegaan op de economische karakteristieken van de Vlaamse Ruit en op de noodzaak om de infrastructurele voorzieningen binnen de Ruit te vernieuwen en uit te breiden. In de vierde sectie gaan we na wat het economisch belang is van de Vlaamse Ruit voor de rest van Vlaanderen. Tenslotte worden de belangrijkste bevindingen samengevat in een besluit.

\section{Een begrippelijk kader om het economisch belang van de Vlaamse Ruit te duiden}

\section{1}

Inleiding

De troeven waarmee de hedendaagse geïndustrialiseerde economieën - en dus ook Vlaanderen - hun economische dynamiek kunnen behouden of versterken kan men onderbrengen in twee categorieën. De eerste houdt verband met de processen om producten of diensten bij de consument te brengen. De tweede gaat na hoe rijke industrielanden op een duurzame wijze goederen en diensten kunnen produceren. De eerste categorie speelt in op de koopkracht van de bevolking in rijke industrielanden en de troeven als gevolg van een gunstige geografische ligging. De tweede onderzoekt de mogelijkheden van kennis als "ressource" bij de productie van goederen en diensten. Deze twee troeven worden onder de loep genomen in de volgende paragrafen. 
In industrielanden zoals België en zijn buurlanden rekent de koopkrachtige bevolking op een ruim aanbod van producten en diensten. Deze koopkracht houdt in dat, ongeacht waar producten geproduceerd zijn, er een groot aantal jobs gecreëerd worden in de logistiek, de marketing en de distributie van deze producten. Daarnaast zorgt welvaart voor heel wat tewerkstelling in de groothandel, kleinhandel, horeca, transport en persoonlijke dienstverlening.

Voor België komt daar nog bij dat de centrale geografische ligging binnen de Europese Unie en de goed functionerende haveninfrastructuur - Antwerpen, Gent en Zeebrugge extra troeven vormen inzake de invoer- en doorvoertrafiek ${ }^{1}$. M.a.w., België kan een deel van de Europese goederenbehandeling en distributie naar zich toe halen tenminste als er voldoende competente dienstverlenende bedrijven bestaan in die branches. Indien die bedrijven er niet zijn worden deze opportuniteiten door buitenlandse bedrijven geëxploiteerd. Binnen dit kader dient ook de rol van de Vlaamse zeehavens gesitueerd te worden. Zij zijn in hoofdzaak invoerhavens - samen met Rotterdam - die allerhande goederen vanuit alle continenten doorsluizen naar de welvarende Europese consument.

De centrale ligging van België / Vlaanderen in Europa wordt ook steeds meer voelbaar in het luchtverkeer. Voor het vervoer van zowel personen als goederen wint de luchthaven van Zaventem aan belang. De belangrijkste trafieken zijn intra-europees: Zaventem heeft een duidelijke hub-functie w.b. het personenverkeer. Naarmate steeds meer sectoren op basis van snelheid concurreren nemen luchthavens ook inzake goederenvervoer een steeds belangrijker functie in: De snelle groei van Brucargo en de verdere ontwikkeling van de luchthaven van Oostende zijn hiervan voorbeelden. Bij congestieproblemen in Zaventem zullen courierdiensten en transportbedrijven hun activiteiten verleggen naar andere nabijgelegen luchthavens zoals Oostende, Bierset en Lille.

Koopkracht alleen vormt doorgaans geen drijvende kracht bij het genereren van toegevoegde waarde of jobs. De koopkracht zal in eerste instantie gegenereerd moeten worden in andere sectoren; De groothandel, kleinhandel, horeca, transport en persoonlijke dienstverlening zorgen in de meeste gevallen alleen voor een multiplicatoreffect ${ }^{2}$. Wanneer de koopkracht in België en/of de Europese Unie verzwakt, zal de economische dynamiek die ermee gepaard gaat, stilvallen.

Kennis en creativiteit als "ressources"

Kennis en creativiteit zijn de belangrijkste vorm van "kapitaal" binnen de hedendaagse

1 Zeebrugge, Gent en Antwerpen zijn in hoofdzaak invoerhavens.

2 Dit sluit niet uit dat bedrijven in een aantal van die sectoren een concurrentiepositie hebben uitgebouwd die veel minder afhankelijk is van de locale koopkracht: bvb. het toerisme in Brugge omwille van het globale karakter van dit soort toerisme. 
westerse economieën. Het bestaan van een goed uitgebouwde (informatie-) infrastructuur, de concentratie van universiteiten en hogescholen, het gemiddeld opleidingsniveau van de arbeiders en de vertrouwdheid met nieuwe technologieën zijn de belangrijkste karakteristieken die geïndustrialiseerde economieën onderscheidt van lage loonlanden. De welvaartscreërende activiteiten in de geïndustrialiseerde landen zullen steeds minder berusten op de allocatie van kapitaal en arbeid. Toegevoegde waarde zal daarentegen steeds meer gegenereerd worden door het productief gebruik van informatie en kennis. Daarom zijn zij de sleutelfactoren geworden om duurzame jobs te creëren in geïndustrialiseerde landen. Vele bedrijven zullen wellicht een aantal arbeidsintensieve waardeactiviteiten (o.a. de productie, assemblage) laten uitvoeren in niet geïndustrialiseerde landen waar de lonen een stuk lager zijn. Maar terzelfdertijd zijn ze voor andere waardeactiviteiten aangewezen op economische en technologische centra binnen de geïndustrialiseerde wereld. Deze waardeactiviteiten maken allemaal intensief gebruik van informatie, kennis en technologie.

Het competitief voordeel van steeds meer bedrijven berust op het creatief omgaan met op kennis gebaseerde diensten - voorbeelden zijn $\mathrm{R} \& \mathrm{D}$, design, human resource development, marketing-informatie, internationale financiering en logistieke systemen. Deze ontwikkeling houdt in dat binnen de "geïndustrialiseerde" landen steeds minder mensen effectief zullen bezig zijn met het produceren van goederen of diensten, en dat er steeds méér mensen betrokken zullen worden in beslissingsprocessen die uitsluitsel geven over wat gemaakt moet worden, hoe de producten geproduceerd moeten worden en hoe ze aan de klant aangeboden kunnen worden.

Voor bedrijven die actief willen zijn in geïndustrialiseerde landen volstaat het accumuleren van kapitaalgoederen of het zwaar investeren in informatietechnologie niet langer om een competitief voordeel op te bouwen of te behouden. Steeds meer bedrijven met activiteiten in geïndustrialiseerde landen danken hun competitief voordeel aan het creatief en strategisch omgaan met informatie. M.a.w., niet de technologie zelf maar de wijze waarop die gebruikt wordt om de waardeketen en de werkprocessen (work processes) te verbeteren en te herstructureren bepaalt of een bedrijf een competitief voordeel kan opbouwen ${ }^{3}$.

\subsection{Enkele implicaties van de kenniseconomie}

Het groeiend belang van informatie, kennis en technologie zal structurele veranderingen voor het soort werk, de opleidingsvereisten, het human resource management, de maatschappelijke solidariteit, en het infrastructuurbeleid met zich meebrengen.

Drucker $^{4}$ argumenteert dat er in de "post-kapitalistische" maatschappij twee klassen zullen

3 Quinn, J.B. en M.N. Baily (1994); “Information technology: Increasing productivity in services”, Academy of Management Executive, Vol 8, No. 3, pp. 28-51.

Normann R. and R. Ramirez (1993); "From value chain to value constellation: Designing interactive strategy", Harvard Business Review, July-August, pp. 65-77

4 Drucker, Peter (1993); Post-capitalist society, Butterworth/Heinemann: Oxford, 198 p. 
zijn, m.n. die van de "knowledge workers" en die van de "service workers". Met "knowledge workers" worden die beroepsactieven bedoeld die op basis van het creatief gebruik van hun kennis (human capital) economische meerwaarde creëren. De tweede klasse van beroepsactieven zijn de "service workers" die niet over de nodige scholing beschikken om als "knowledge worker" aan de slag te gaan.

Reich $^{5}$ onderscheidt drie soorten jobs volgens een min of meer gelijklopend patroon. "Creatieve bijdragen" (meestal door hooggeschoolden) vormen de eerste categorie: ingenieurs, "public relations"-mensen, juristen, managers, ontwerpers, financiers, schrijvers, kunstenaars, journalisten e.a. behoren tot die categorie. Het gaat om het creatief aanwenden van kennis en ervaring om problemen te identificeren, op te lossen en de implementatie van de oplossing te plannen. Dit soort werk is interessant en het wordt doorgaans goed betaald omdat de jobs een hoge toegevoegde waarde realiseren. Een tweede categorie wordt gevormd door de routineproductie en -diensten. Hieronder ressorteren bandwerkers, het middenkader, controle jobs, loonadministratie, enz... De toekomst voor routine-jobs is niet rooskleurig omwille van de toenemende automatisering en de concurrentie van lage loonlanden. Men mag zich aan een geleidelijke afbouw van routinetaken verwachten, met inbegrip van het middenkader en het routinemanagement. Zelfs een drastische loonkostendaling kan het tij niet keren en zal het aftakelingsproces hoogstens afremmen. Een laatste categorie zijn de gepersonaliseerde diensten. Dit zijn routinetaken waarbij men in rechtstreeks contact staat met de klant: voorbeelden zijn hotelpersoneel, kappers, ziekenhuispersoneel, taxibestuurders, installateurs, enz... De gepersonaliseerde diensten zitten evenmin goed: Stijgende lonen gecombineerd met het feit dat de productiviteit in heel wat van die diensten nauwelijks kan opgedreven worden, impliceren dat de gepersonaliseerde diensten gedurende de laatste decennia relatief duur geworden zijn. Deze evolutie stimuleert uiteraard het zwart arbeidscircuit ${ }^{6}$. In de mate dat deze jobs gebonden zijn aan de locale economie kan een serieuze reductie in de loonkost (maar niet in het nettoloon) soelaas brengen voor dit soort jobs.

De twee grote uitdagingen voor de toekomst zijn het verhogen van de arbeidsproductiviteit van de kenniswerkers en het herdenken van de sociale solidariteit om een sociaal conflict, dat zou kunnen groeien vanuit de sociale onvrede van de dienstenwerkers, te vermijden.

De arbeidsproductiviteit van de kenniswerkers zal bepalend zijn voor de welvaart in de post-industriële maatschappij. In het verleden hebben "kennis-jobs" een zwakke productiviteitsgroei gekend. Tegenwoordig komt daar verandering in: Een groot deel van de productiviteits-verbeteringen wordt geïnduceerd door het effectief en strategisch gebruik van de informatietechnologie ${ }^{7}$. Recente gegevens wijzen uit dat de IT-infrastructuur de arbeidsproductiviteit kan verhogen onder bepaalde voorwaarden. De beste resultaten

$5 \quad$ Reich, Robert (1992); The work of nations, New York, 339 p.

6 Het VEV (Op weg naar groei, Uitgeverij Pelckmans, 159 p) berekende dat het voor de consument $71 \%$ goedkoper was om een schilder in het zwart te betalen i.v.m. een volledig legale transactie.

7 Quinn, Brian en Martin Neil Baily (1994); "Information technology: Increasing productivity in services", Academy of Management Executive, Vol 8, No. 3., pp. 28-51. 
worden verkregen wanneer de IT-infrastructuur geïntegreerd wordt als een strategische investering binnen "business process re-engineering"-initiatieven of herformuleringen van de bedrijfsstrategie. IT dient niet om dezelfde dingen vlugger te doen: Integendeel, goeie toepassingen van IT herdefiniëren het werk van de werknemers en ze verbinden functies die voorheen gescheiden waren. Steeds meer bedrijven worden zich daarvan bewust, zodat ITinvesteringen steeds meer beschouwd worden als een belangrijk middel om een competitief voordeel te verwerven ${ }^{8}$. Het verhogen van de arbeidsproductiviteit ten gevolge van ITinvesteringen zal m.i. dan ook sterk toenemen gedurende het volgende decennium. $\mathrm{Nu}$ al is die trend zichtbaar door de toenemende uitstoot van routinematige jobs in de bank- en verzekeringswereld. Ook in de groothandel, logistiek en transportsector zal die trend zich doorzetten, zodat we kunnen aannemen dat het aantal routinematige jobs in de dienstensector zal terugvallen.

De toekomst voor routine-jobs of "service workers" ziet er dus slecht uit. Alleen creatieve jobs of "knowledge workers" kunnen rekenen op goeie tewerkstellingskansen. De kans is evenwel groot dat het aantal nieuwe arbeidsplaatsen voor creatieve jobs op middellange termijn niet voldoende zal zijn om de arbeidsuitstoot van routine-jobs op te vangen. Daarenboven zijn heel wat mensen niet gekwalificeerd om te werken als "knowledge worker": zelfs met het beste onderwijs- en opleidingssysteem zal dat niet veranderen. M.a.w., het risico voor een duale maatschappij is groot en is een groeiend probleem voor de verantwoordelijke beleidsmakers. Binnen de context van dit rapport kunnen we evenwel niet dieper ingaan op deze problematiek.

In het volgend punt gaan we na hoe de overgang van een industriële economie naar een kenniseconomie gekoppeld kan worden aan de noodzaak om een grootstedelijk netwerk op internationaal niveau uit te bouwen.

De kenniseconomie en het belang van een grootstedelijk netwerk op internationaal niveau

\section{Een proactief economisch beleid}

Rijke industrielanden zullen zich steeds meer moeten toeleggen op het creëren van "creatieve jobs" en het verhogen van hun productiviteit. Steeds méér routinejobs worden door de bedrijven geheralloceerd naar lage loonlanden. Dit is het geval voor een aantal industriële assemblage- en productie-activiteiten, maar ook voor routinematige diensten - bvb. software wordt aan bedrijven in Indië en andere lage loonlanden uitbesteed. Delocalisatie is dus niet gebonden aan industriële activiteiten, maar wel aan een bepaald soort werk, m.n. routine-jobs. Ook routinematige jobs in hoogtechnologische sectoren zullen uitbesteed

8 De IT-infrastructuur heeft in vele gevallen ook nieuwe dienstverlening mogelijk gemaakt - bvb. het online opsporen van goederen in bestelling - of er is sprake van kwaliteitsverbeteringen - bvb. het invoeren van geldautomaten betekent een betere dienstverlening inzake geldopname omwille van de 24-uur service en de grote verspreiding van die automaten. 
worden naar lage loonlanden, omdat het aantal geschoolden in ontwikkelingslanden systematisch toeneemt.

M.b.t. de opkomst van de kenniseconomie ziet men in menig industrieland - ook in België / Vlaanderen - een defensieve, protectionistische beleidsreflex: Door het beschermen van "te dure" routine-jobs worden de bedrijven minder concurrentieel waardoor de rekening achteraf in termen van tewerkstellingsverlies nog zwaarder zal uitvallen. Het economisch beleid dient daarentegen proactief te zijn: het moet de bedrijven stimuleren om te penetreren in exportmarkten, om hun kansen te wagen met nieuwe technologieën en producten, en om zich organisatorisch te herstructureren. De vernieuwde competitiviteit zal vermoedelijk gepaard gaan met het opzetten van buitenlandse filialen en met minder binnenlandse tewerkstelling in de eigenlijke productie. Daartegenover staat dat nieuwe (nieuwsoortige) jobs gecreëerd zullen worden in het binnenland, onder meer in de concernleiding, research, productontwikkeling, marketing, logistiek, enz... Een economisch beleid dient men niet te evalueren aan het aantal jobs dat door delocalisatie verloren gaat, maar wel aan wat ervoor in de plaats komt. Een succesvol proactief beleid creëert nieuwe jobs met hoge toegevoegde waarde en zorgt ervoor dat binnenlandse bedrijven de kans krijgen om concurrentieel en winstgevend te blijven. Dit heeft op zijn beurt positieve gevolgen voor de belastingontvangsten, de opleidings- en kennisinfrastructuur, en de medische en socioculturele voorzieningen.

Het economisch beleid en de uitbouw van een grootstedelijk netwerk op internationaal niveau

Een rijk industrieland zoals België met een hoog gemiddeld onderwijs- en opleidingsniveau dient te concurreren op basis van het hoge kennisniveau van de arbeidskrachten. De kennis en de kennisinfrastructuur zijn - samen met de koopkracht - de enige resources waarover de industrielanden wel en de NILs (Nieuw Geïndustrialiseerde Landen) en de ontwikkelingslanden niet beschikken. Het bereiken van een hoog gemiddeld opleidingsniveau is een werk van lange adem, zodat kennis een duurzame bron van welvaart en competitieve voordelen kan zijn; "Knowledge workers" onderscheiden zich van "service workers" - en creatieve jobs van routine-jobs - omdat de eerste soort arbeid veel moeilijker kan verplaatst worden naar NILs of ontwikkelingslanden.

Kennis creëert evenwel enkel welvaart wanneer de dure, goed gevormde werknemers zo ingezet worden dat ze een meerwaarde genereren die hun hoge lonen ruimschoots vergoeden. Het efficiënt gebruik van human capital in een industriële of dienstenonderneming vertaalt zich in kwaliteitsverbeteringen, proces- en productvernieuwingen en immateriële productie. In België wordt het enorme reservoir aan human capital niet productief aangewend: België scoort in de export ondermaats in sectoren die intensief gebruik maken van human capital ${ }^{9}$. Dit heeft onder meer te maken met het feit dat investeringen in materiële

9 Tharakan, P. en J. Waelbroeck (1988); “Has human capital become a scarce factor in Belgium?”, Cahiers économiques de Bruxelles, $\mathrm{N}^{\circ} 118$, 2ème trimestre, pp. 159-179. 
activa (gebouwen, machines) zwaarder gesubsidieerd worden dan deze in immateriële activa. Omdat kennis "gedragen" wordt door werknemers - "knowledge workers" - kan men sociale zekerheidsbijdragen en directe belastingen beschouwen als een taxatie op human capital: in die zin legt men de zwaarste lasten op de productiefactor met de grootste economische troeven.

Niet alleen de overheid maar ook het management hypothekeert in veel gevallen de efficiente werking van goed gevormde werknemers. Al te vaak worden (hoog)geschoolde werknemers ingezet als "domme krachten". De productie in landen als België is te duur als de mogelijkheden van goed gevormde werknemers (in termen van arbeidsproductiviteit) onderbenut blijven.

Er dient dus in België nog één en ander te veranderen. Het economisch beleid zou op een proactieve wijze moeten kunnen inspelen op de opkomst van de kenniseconomie. Maar zijn regionale beleidsacties wel verantwoord in een tijd waar bedrijven wereldwijd concurreren? Deze vraag kan maar beantwoord worden door ze te vervangen door twee deelvragen. Een eerste peilt in welke mate de competitiviteit van bedrijven bepaald wordt door de locale economische en maatschappelijke omgeving. Een regionaal economisch beleid heeft slechts zin als er een positief antwoord komt op deze vraag. Vervolgens dient men te onderzoeken welke inputs de streekeigen ondernemingen beter betrekken vanuit andere regio's en landen en welke moeten ontwikkeld en gerealiseerd worden in de eigen subregio.

Men kan zich terecht afvragen wat de economische rol van een regio als Vlaanderen kan zijn in een tijd waar bedrijven wereldwijd concurreren. Het laatste decennium is er heel wat gepubliceerd over de thematiek hoe de locale economie en infrastructuur bijdragen tot de internationale competitiviteit van bedrijven ${ }^{10}$. De conclusie van deze studies is duidelijk: Hoe paradoxaal het ook mag klinken, locale processen zijn sleutelfactoren in het verklaren van de internationale competitiviteit van bedrijven. We kunnen hier onmogelijk de theorie omtrent het belang van locale economische processen herhalen. De twee volgende citaten geven de kern van de argumentatie weer:

"Competitive advantage is created and sustained through a highly localized process. ...The role of the home nation seems to be as strong or stronger than ever. While globalization of competition might appear to make the nation less important, instead it seems to make it more so."11

"In global competition, the key elements of economic performance and strategy are

$10 \quad$ Hall, P. en Markusen, A. (1985); Silicon landscapes, Boston: Allen and Unwin. Saxenian, A. (1995); Silicon Valley and Route 128: regional prototypes or historical exceptions?, in M. Castells (ed.) High technology, space and society, Beverly Hills: Sage.

Porter, M. (1990); The competitive advantage of nations, London: MacMillan.

Krugman, P. (1991); Geography and trade, Cambridge: The MIT Press.

11 Porter, M. (1990); The competitive advantage of nations, p. 19. 
intensely local."12

Voortgaande op het recent onderzoek van deze auteurs kan men besluiten dat locale economische processen en infrastructurele voorzieningen een significant positieve impact kunnen hebben op de internationale competitiviteit van bedrijven. De regionale economische structuur en infrastructurele voorzieningen zijn dus belangrijk voor de internationale competitiviteit van de bedrijven. Maar in een snel veranderende en internationaliserende economische omgeving zijn bedrijven verplicht om steeds meer inputs en ondersteunende activiteiten te betrekken van buiten de eigen regio. Door het openstellen van de grenzen en de daarmee gepaard gaande sterkere concurrentie tussen regio's, landen en continenten gaan ondernemingen op zoek naar de beste productiefactoren tegen de beste prijs. Deze internationale zoektocht van bedrijven naar de beste productiefactoren houdt in dat de regio's alleen dan attractief zijn voor bedrijven als ze iets unieks te bieden hebben, iets dat de bedrijven in andere regio's niet kunnen vinden.

Door de toenemende globalisering staan de economische en technologische centra binnen de geïndustrialiseerde wereld dus in onderlinge concurrentie en bedrijven zullen hun waardeactiviteiten ten dele localiseren in functie van de (technologische) competentie van de locale economieën. Deze zoekacties van bedrijven naar centers of excellence veroorzaken geografische concentraties van instituten en bedrijven die een leidinggevende rol vervullen op het vlak van een bepaalde technologie, discipline of economische activiteit. Regionale economieën die geen competenties kunnen ontwikkelen op basis van informatie en/of technologie, zullen gekonfronteerd worden met een dalende concurrentiepositie t.o.v. andere regionale economieën binnen de geïndustrialiseerde wereld ${ }^{13}$.

Het regionaal economisch beleid dient dan ook twee complementaire acties te ondernemen. Ten eerste dient het ervoor te zorgen dat bedrijven in de subregio gemakkelijk toegang krijgen tot de (productie)factoren in andere regio's en landen. M.a.w., het beleid dient ervoor te zorgen dat de regio aansluit bij belangrijke economische centra. Het belang ervan kan geïllustreerd woorden a.d.h.v. nieuwe infrastructuurwerken zoals bvb. de HST. De HST brengt grote economische centra dichter bij elkaar maar terzelfdertijd vergroot hij de relatieve afstand tussen economisch perifere gebieden en de nabijgelegen grote economische centra $^{14}$. M.a.w., de geografische afstand is niet langer synoniem voor de economische afstand. Hier ligt een belangrijke opgave voor de uitbouw van de Vlaamse Ruit; Door tot een belangrijk economisch centrum uit te groeien met goed uitgebouwde connecties met andere grote economische en technologische centra in Europa en de rest van de wereld kan de Vlaamse Ruit ervoor zorgen dat de Vlaamse economie een centrale rol kan (blijven) spelen binnen de E.U. en de wereldeconomie. Door de groeiende concurrentie tussen de regio's is het best mogelijk dat Vlaamse / Belgische economie in de geo-economische "marginaliteit" terecht komt wanneer men er niet in slaagt om van de Vlaamse Ruit een

12 Gabor, A. (1991): “ A community's core competence”, Harvard Business Review, July-August, p. 116.

13 Porter, Michael (1990); The competitive advantage of nations, The MacMillan Press: London, 855 p.

14 Vanhaverbeke W. (1994); Euro-regio: Een strategie voor Zuid West-Vlaanderen op basis van complementaire sterktes met de regio Nord - Pas-de-Calais, Kortrijk: Charter 99, 202 p. 
grootstedelijk netwerk met een internationale uitstraling te maken.

Terzelfdertijd dient het regionaal beleid na te gaan welke infrastructurele voorzieningen in de regio zelf een onmiskenbaar effect (kunnen) hebben op de competitiviteit van de bedrijven. Men kan niet langer uitgaan van de filosofie om infrastructurele voorzieningen zo gespreid mogelijk - d.i. per provincie of per streek - uit te bouwen. Dit leidt zondermeer tot economische mediocriteit omdat heel wat infrastructurele voorzieningen een grootstedelijk gebied als economische onderbouw vereisen. Het spreekt vanzelf dat deze voorzieningen ook rekening moeten houden met de herstructurering van de economie tot een kenniseconomie. Alleen die initiatieven die tot een center of excellence kunnen uitgroeien verdienen de nodige aandacht. Centers of excellence onderscheiden zich van minder succesvolle voorzieningen doordat ook buitenlandse bedrijven voor de diensten van deze voorzieningen willen betalen. In die zin moet het economisch beleid steunen op een "local for global"-strategie $^{15}$.

In deze sectie zijn de economische troeven van Vlaanderen in kaart gebracht. Eigenlijk gaat het om twee kritische succesfactoren waarbij de uitbouw van de Vlaamse Ruit als een grootstedelijk netwerk met internationale uitstraling een essentiële rol dient te spelen. Deze twee troeven kunnen als volgt samengevat worden. Vlaanderen dient zijn rol als belangrijke invoer- en doorvoerland in de E.U. te versterken. De economische impact van deze troef wordt in grote mate bepaald door de "poorten"-infrastructuur in havens en luchthaven(s), door de mobiliteit door verschillende transportmodi, door de sociale rust en arbeidsflexibiliteit en door de aanwezigheid van een grote waaier van verschillende gespecialiseerde dienstverlening t.b.v. het bedrijfsleven.

De tweede is de opkomst van de kenniseconomie. De economische impact van deze troef is fundamenteler dan die van de eerste en de uitdagingen voor het economisch beleid zijn ook veel groter. De omvorming van een industriële economie naar een kenniseconomie kan slechts slagen als Vlaanderen / België een grootstedelijk netwerk met internationale uitstraling kan uitbouwen. De Vlaamse Ruit zal dan een dubbele rol spelen. Enerzijds herbergt ze een aantal infrastructurele voorzieningen die een grootstedelijk gebied als kritische massa nodig hebben. Anderzijds zal de Vlaamse Ruit de schakel vormen waardoor de rest van Vlaanderen / België aansluiting krijgt met grote economische en technologische centra in de E.U. en de rest van de wereld.

Om na te gaan of de Vlaamse Ruit die rol kan waarmaken dienen we na te gaan wat de economische karakteristieken zijn van de Vlaamse Ruit. Dit is het onderwerp van de volgende sectie. In sectie vier gaan we na welke impact de Vlaamse Ruit heeft op de economie in de rest van Vlaanderen.

15 Een "local for local"-strategie zou nefaste gevolgen hebben voor de economische attractiviteit van de regio op middellange termijn. 


\section{Het economisch belang van de Vlaamse Ruit}

\section{$3.1 \quad$ Inleiding}

In deze sectie geven we een kort overzicht van de belangrijkste economische karakteristieken van de Vlaamse Ruit. Terzelfdertijd wordt nagegaan of de Vlaamse Ruit wel de mogelijkheden heeft om uit te groeien tot een grootstedelijk netwerk op internationaal niveau.

Naast de kwantitatieve beschrijving is het ook belangrijk om aan te tonen hoe de uitbouw van de Vlaamse Ruit de concurrentiële slagkracht van bedrijven kan versterken. Ten slotte wordt nagegaan in welke mate de verschillende grootstedelijke gebieden een complementaire rol kunnen vervullen binnen de Vlaamse Ruit.

In 1991 werkten er 1.536 .752 personen in de Vlaamse Ruit. Dit is $42,8 \%$ van de tewerkstelling in België. In vergelijking met 1981 is dat een toename van de tewerkstelling met $3,1 \%$. Dit groeicijfer ligt $0,8 \%$ lager dan dat voor gans België voor dezelfde periode. Dit is een eerste belangrijk probleem; De Vlaamse Ruit, die een economisch concentratiegebied en een groeipool zou moeten zijn, is er niet in geslaagd om die rol echt waar te maken tijdens het laatste decennium.

Er zijn een aantal redenen waarom het "hart" van de Belgische economie aan het "sputteren" gaat:

- $\quad$ Er is i.v.m. buitenlandse voorbeelden sinds het midden van de "70er jaren uitzonderlijk weinig geïnvesteerd door de overheid in infrastructurele voorzieningen in de Vlaamse Ruit.

- $\quad$ De steeds complexere wetgeving (o.a. inzake bouw- en milieuvergunningen) en de trage besluitvorming weerhouden bedrijven om te investeren.

- Relatief weinig beschikbare industriegronden gekoppeld aan de groeiende problemen inzake bereikbaarheid (verkeerscongestie) weerhoudt bedrijven om zich te localiseren in de Vlaamse Ruit.

- Dicht netwerk van autosnelwegen laat toe dat bedrijven zich localiseren net buiten de Vlaamse Ruit (erosie van de Vlaamse Ruit) of in het buitengebied van de Vlaamse Ruit.

16 Dit deel van het rapport steunt op de bevindingen van volgende rapporten:

Meuris F. en M. Jurriëns (1996); Vlaamse Ruit, Deelrapport 1: Oriëntatie en selectie relevante groepssectoren, ISRO - KUL, $10 \mathrm{p}$.

Meuris F. en M. Jurriëns (1996); Vlaamse Ruit, Deelrapport 2: Ruimtelijke differentiatie geselecteerde groepssectoren, ISRO - KUL, $28 \mathrm{p}$.

Vanhaverbeke, W. et al. (1993); Economisch profiel van de Vlaamse stadsgewesten, K.U.L. - IISRO, Leuven, 319 p. 
- Verval van verschillende binnensteden waardoor een deel van de tewerkstelling (bvb. horeca) verloren gaat.

- Opkomst van winkelketens die zich langs belangrijke secundaire wegen vestigen.

Verlies van dynamisme van grotere stadsgewesten i.v.m. verschillende kleinere stadsgewesten die profiteren van de doorgroei van een groot aantal KMO's in relatief jonge sectoren zonder dat dit effect teniet gedaan wordt door de afbouw van tewerkstelling door bedrijven in mature sectoren.

In de figuur op de volgende bladzijde zijn de specialisatiecoëfficient (voor 1991) en de relatieve groei van de verschillende economische sectoren weergegeven. Het grootste deel van de sectoren waarin de Vlaamse Ruit gespecialiseerd is zijn dienstverlenende sectoren: internationale organisaties, bank- en verzekeringswezen, hoger onderwijs en O\&O, groothandel, immobiliën, bedrijfsgerichte dienstverlening, vervoer, communicatie en amusement. Er zijn ook een aantal sterk vertegenwoordigde industrieën: transportmiddelen, papier en grafische industrie.

Deze sectoren zijn niet toevallig sterk vertegenwoordigd in een gebied dat de ambities heeft om een grootstedelijk netwerk te worden met internationale uitstraling. In een grootstedelijk gebied verwacht men een duidelijke concentratie van hoger onderwijs, O\&O, internationale organisaties, bedrijfsgerichte dienstverlening, banken en verzekeringsmaatschappijen, groothandel, communicatie en immobiliën. Ook high-tech industrieën zoals elektrotechniek kan men er verwachten omwille van de nabijheid van universiteiten en technologie ondersteunende instituten. De concentratie van de grafische nijverheid is ook een logisch gegeven aangezien deze sector vooral toelevert aan de grote concentratie van kantoren binnen de Vlaamse Ruit.

Het feit dat de Vlaamse Ruit minder snel groeide dan de rest van België wordt weerspiegeld in de figuur door het relatief groot aantal sectoren (waaronder belangrijke in termen van absolute tewerkstelling) dat onder de nullijn ligt van de relatieve groei. M.a.w., de economische positie van de Vlaamse Ruit is langzaam aan het eroderen. Redenen hiervoor zijn hierboven reeds vermeld. Indien men de Vlaamse Ruit haar internationale uitstraling wil geven zal hierin een trendbreuk moeten gerealiseerd worden.

In de volgende figuur zijn de relatieve groei van de Vlaamse Ruit t.o.v. België en de groei van dezelfde sectoren in België weergegeven. Met deze figuur kunnen we nagaan hoe de positie van de Vlaamse Ruit veranderd is in progressieve en regressieve sectoren. De sectoren rechts (links) van de schuine lijn zijn deze met een positieve (negatieve) tewerkstellingsgroei in 1981-1991. Deze figuur wijst uit dat de Vlaamse Ruit gespecialiseerd is in sectoren die progressief zijn (enkele uitzonderingen niet te na gesproken). Ook hier weer geldt de opmerking dat de Vlaamse Ruit niet in staat is om in die progressieve sectoren even snel te groeien als de rest van België. M.a.w., de economische specialisatie van de Vlaamse Ruit is van die aard dat de tewerkstellinggroei aanzienlijk zou moeten zijn maar om de hierboven vermelde redenen slaagt zij er niet in om even snel te groeien in die sectoren als de rest van België. Alleen de groothandel en de vrije tijdssector zijn de enige twee speciali- 
saties van de Vlaamse Ruit die een hoger groeiritme konden aanhouden (in termen van tewerkstelling) dan de rest van België. 
Voor zes sterk vertegenwoordigde sectoren (chemie, transportmiddelen, groothandel, communicatie, vervoer, bedrijfsgerichte dienstverlening) is een verdere opsplitsing gemaakt naar de verschillende types van stedelijke gebieden binnen de Vlaamse Ruit. Uit de gegevens blijkt de dominante rol van de grootstedelijke gebieden: In elk van de zes sectoren vertegenwoordigen zij meer dan $80 \%$ van de tewerkstelling. Opmerkelijk is ook hoe hun dominante positie erodeerde gedurende de periode 1981-1991 ten voordele van kleinstedelijk provinciale gebieden, maar vooral van het buitengebied. Ook dit is een probleem: De grootstedelijke gebieden in de Vlaamse Ruit zijn niet langer in staat hun dominante economische positie binnen de Vlaamse Ruit te bestendigen. Een aantal van de hiervoor vermelde redenen liggen aan de grondslag van deze erosie. Ook hier is een trendbreuk - althans vanuit het perspectief van de ruimtelijk ordening - wenselijk.

\subsection{Een grootstedelijk netwerk als grondslag van concurrentiële voordelen}

De economie in de Vlaamse Ruit vervult t.o.v. de rest van Vlaanderen een belangrijke rol. Naarmate de nationale en regionale economieën in de E.U. steeds meer steunen op snelle verbindingen tussen belangrijke economische concentratiegebieden, kan men de Vlaamse Ruit zonder meer beschouwen als de poort voor de rest van Vlaanderen op de belangrijkste economische concentratiegebieden in Europa. Via de drie grote havens is Vlaanderen gelocaliseerd temidden belangrijke handelsstromen tussen het Europese vasteland en de rest van de wereld (vooral via de invoertrafiek). Via de luchthaven van Zaventem en de nieuwe HST-stations is men steeds op een boogscheut verwijderd van de hoofdassen van het Europese (en internationale) personenvervoer. Met Brussel als centrum van de E.U. en van talrijke internationale organisaties - naast de federale en regionale politieke instanties - is men nooit verder dan een uur verwijderd van het politieke centrum van Europa. Daarenboven functioneren de grootstedelijke gebieden in de Vlaamse Ruit als attractiepolen voor allerlei hoogwaardige dienstverlening. Tenslotte bieden grootstedelijke netwerken ook een niet te versmaden aanbod van universiteiten en onderzoekslaboratoria aan, wat de attractiviteit van de regio en technologische competentie van de bedrijven kan versterken.

De economische meerwaarde die gegenereerd wordt door de nabijheid van een grootstedelijk netwerk met internationale uitstraling kan moeilijk onderschat worden. Op minder dan een uur tijd kan om het even welk bedrijf in Vlaanderen een beroep doen op een ruime waaier van diensten en infrastructurele voorzieningen die zonder grootstedelijk draagvlak niet zouden kunnen bestaan. Uit interviews met bedrijfsleiders blijkt dat bedrijven uit de rest van Vlaanderen vooral voor logistieke activiteiten en voor allerhande generieke dienstverlening een beroep doen op de Vlaamse Ruit gedaan. Men is over het algemeen heel tevreden over die dienstverlening. De afstand is geen probleem want $100 \mathrm{~km}$ is voor de meeste dienstverlening- en communicatiebehoeften gemakkelijk te overbruggen.

De keerzijde van de medaille is dat verschillende grootstedelijke netwerken concurreren met elkaar voor het aantrekken van economische activiteiten. Voorbeelden zijn het aantrekken van havenactiviteiten, courierdiensten, hoogwaardige dienstverlening in het financiewezen en de verzekeringswereld, high-tech bedrijven, enz... Om die attractiviteit te behouden en 
te versterken dient er continue gë̈nvesteerd te worden in de infrastructurele voorzieningen binnen de Vlaamse Ruit. Hierbij dient speciaal aandacht besteed te worden aan deze componenten die de internationale uitstraling van het grootstedelijk netwerk versterken.

Zoals we reeds aanhaalden in de vorige sectie, zijn er een reeks indicaties die erop wijzen dat de Vlaamse Ruit zijn rol als grootstedelijk netwerk met internationale uitstraling niet echt waarmaakt. De reden dient men te zoeken in een gebrek aan beleidsvisie want de Vlaamse Ruit heeft zeker inherent de mogelijkheden om uit te groeien tot een echt grootstedelijk netwerk met een internationale uitstraling.

In een ander rapport ${ }^{17}$ is reeds gewezen op het feit dat de Vlaamse Ruit "het helemaal / allemaal heeft". In vergelijking met andere stedelijke netwerken van hetzelfde niveau heeft de Vlaamse Ruit een voldoende stedelijk draagvlak; ze heeft een groot en gedifferentieerd woningaanbod; er is een hoog opgeleide en mobiele bevolking; ze is een concentraatgebied van werkgelegenheid met hoge arbeidsproductiviteit; ze herbergt veel zetels van top-bedrijven; ze is het bestuurscentrum van Europa en het nationaal financieel centrum; er zijn kunststeden met een mundiale uitstraling; ze is het derde congrescentrum van de wereld; er zijn specifieke stedelijke voorzieningen en een dicht kleinhandelsapparaat. De hierboven vermelde economische gegevens wijzen evenwel op de erosie van de economische slagkracht van de Vlaamse Ruit.

\subsection{Complementariteit tussen de grootstedelijke gebieden in de Vlaamse Ruit}

In deze sectie overlopen we eerst op summiere wijze de belangrijkste karakteristieken van de grootstedelijke gebieden in de Vlaamse Ruit ${ }^{18}$. Daarna gaan we in op de complementariteit tussen deze grootstedelijke gebieden.

\section{Brussel}

In de afgelopen 15 jaar werd de economische ontwikkeling in het Brussels grootstedelijk gebied enerzijds gekenmerkt door een terugval in de traditionele hoofdstedelijke funkties. Anderzijds heeft zich een sterke dynamiek ontwikkeld in de dienstverlening. Gedeeltelijk is die tertiarisering te verklaren door de verdere opgang van de dienstverlening in de Westerse economieën in het algemeen en de hoofdstedelijke funkties van Brussel in het bijzonder. De zakelijke dienstverlening, de financiële sector en overige diensten hebben dan ook een stevige dynamiek gekend. Specifiek voor Brussel is de rol van internationaal beslissingscentrum een belangrijke stimulerende factor geweest die de kracht van de dynamiek heeft bepaald. Ook een aantal grote bedrijven die belangen hebben bij de E.U. worden aangetrok-

Arohm (1996); Een functionele en morfologische basis voor de Vlaamse Ruit: Sneuvelnota - 5 oktober 1996, Arohm- afdeling Ruimtelijke Planning, 31 p.

18 Een meer gedetailleerde beschrijven van de Vlaamse stadsgewesten vindt men in:

Vanhaverbeke, W. et al. (1993); Economisch profiel van de Vlaamse stadsgewesten, K.U.L. - IISRO, Leuven, 319 p. 
ken door die beslissingsmacht.

De beschreven dynamiek heeft tevens gezorgd voor een belangrijke ruimtelijke ontwikkeling. Het centrum van Brussel heeft een grote aantrekkingskracht op de verschillende politieke en economische agenten. De nationale en internationale beslissingsmacht staan er centraal. Aktiviteiten die daar niet in passen vinden het centrum van Brussel niet de ideale plaats om in te werken. De rand rond Brussel vangt die druk op. De economische agenten die een combinatie zoeken van centrale ligging, bereikbaarheid in de nationale markt, nabijheid van Zaventem en van het nationaal en Europees beslissingscentrum vinden de rand van Brussel een aantrekkelijke locatie.

Door de aanwezigheid van de internationale instellingen en organisaties is Brussel zich aan het ontwikkelen tot een knooppunt van informatie en internationale relaties. Dit geeft een groot potentieel voor de verdere ontwikkeling van tertiaire en kwartaire aktiviteiten. Investeringen in de inputfactoren zullen hierbij beslissend zijn voor het succes. Het betreft investeringen in mensen door onderwijs en opleiding, in infrastructuren voor fysische verbindingen en telecommunicatie, in een aantrekkelijk leef -en werkmilieu. De endogene dynamiek die hierdoor gegenereerd kan worden zal de druk op de rand rond Brussel nog verhogen; Beleidsmakers dienen dus dringend werk te maken van significante infrastructurele verbeteringen in dit gebied.

\section{Antwerpen}

De economische ontwikkeling van het stadsgewest Antwerpen blijft onlosmakelijk met de haven verbonden. Een haven heeft eigenlijk vier funkties. Ze is een schakel in de logistieke keten en vormt een vast punt voor goederenoverslag. Daarnaast kunnen ook de industriële functie, de handelsfunctie en de opslag en distributie worden uitgebouwd. Het belang van de ontwikkeling van deze funkties ligt in de toegevoegde waarde die op deze wijze in de fases van de waardeketen volgend op het transport van de goederen ook in de regio wordt gerealiseerd. De regio Antwerpen is daar steeds sterk in geweest. De invulling van de funkties heeft er voor gezorgd dat veel sectoren actief zijn in het stadsgewest en dat deze sectoren tevens op een of andere wijze met de haven verweven zijn.

Dat die verschillende funkties in het stadsgewest Antwerpen zo goed tot ontwikkeling konden komen is te danken aan haar grote aantrekkingskracht. Naast de aanwezigheid van de haven heeft de regio een centrale en diep landinwaartse ligging tegenover haar Europees hinterland. Er is een groot aanbod van vervoersmogelijkheden en de bereikbaarheid is zeer goed maar bedreigd door de congestie in het verkeer. De brede basis van economische aktiviteiten die in het stadsgewest Antwerpen werd opgebouwd biedt op zijn beurt mogelijkheden voor toelevering, uitbesteding en dienstverlening.

Het valt tevens op dat de industrie in Antwerpen relatief snel groeit en haar positie in vele gevallen verstevigde. Antwerpen is een is een aantrekkelijke omgeving voor industriële bedrijven. Bovendien zijn er naast de havengebonden specialisaties sterke posities in de telecommunicatie en precisieinstrumenten, de diamantsector en de uitgeverijen. Ook in de 
elektromechanische industrie en machinebouw bestaat een stevige basis. Het is duidelijk dat de economie in Antwerpen niet enkel op de haven steunt en over een aantal andere belangrijke sectoren beschikt. Het strategisch plan van de regio Antwerpen wil de aantrekkelijke voorwaarden scheppen en mogelijke knelpunten opruimen om haar industrieel en economisch weefsel verder te laten ontwikkelen.

Het stadsgewest Antwerpen is uitgegroeid tot een draaischijf voor het nationaal en internationaal transport. Er is een grote concentratie aan goederenstromen met een grote verscheidenheid in trafieken en een groot aantal bestemmingen en herkomst (draaischijf van goederenstromen). Verder is er een groot aanbod in transportmogelijkheden (draaischijf van transportmodi). De troeven van Antwerpen en de ontwikkelingen in logistiek en distributie bieden heel wat perspectieven.

In combinatie met de ontwikkeling van de verschillende funkties en de grote aantrekkingskracht die Antwerpen heeft, kan men wellicht spreken van een geïntegreerd knooppunt ${ }^{19}$. Er bestaan verschillende "kruiselingse" verbanden: dit is o.a. het geval tussen de haven pijplijnen - petroleumindustrie - chemische en petrochemische industrie - goederenbehandeling. Een ander voorbeeld betreft de havenindustrie en het binnenscheepvaartverkeer die erdoor gegenereerd wordt. In verschillende trafieken blijkt ook dat het belangrijk is om de overslag, opslag, distributie en overige behandelingen van een trafiek in één dienstenpakket te kunnen aanbieden ("full distribution"). Dit wijst er op dat in het stadsgewest Antwerpen verschillende aktiviteiten op een geïntegreerde manier samenwerken en zo een competitief voordeel kunnen verwerven.

\section{Gent}

Om de positie en de rol van Gent in een juist perspectief te plaatsen dient met dit grootstedelijk gebied situeren binnen de driehoek van de steden Antwerpen, Brussel en Lille. Elk van deze steden is een belangrijke Europese metropool of grootstad. In de internationale concurrentie tussen de Europese steden hebben zij belangrijke troeven en elk hun eigen rol: Antwerpen als wereldhaven en Europees distributiecentrum (draaischijf), Brussel als hoofdstad van de E.U. en Lille als belangrijkste centrum van Noord-Frankrijk en poort naar Engeland. Deze steden zijn ook aangesloten op internationale vervoersnetwerken door middel van de HST en luchthavens. Deze steden beschikken ook over voldoende economische en politieke macht. Gent mist die dimensie van deze drie steden. Het zou dan ook een illusie zijn Gent tot op het niveau van een Europese metropool te willen verheffen. De potentialiteiten liggen op een lager hiërarchisch niveau dan dat van een Europese metropool.

In het noorden ligt de havenzone. Die geeft het stadsgewest een belangrijke industriële pool waar ook distributieactiviteiten verder kunnen uitgebouwd worden. In het zuiden van het stadsgewest komt een moderne en multifunctionele site tot stand. Het biedt Gent de mogelijkheden voor diversificatie in diensten en technologie. Deze site is goed bereikbaar, biedt 
imago en voldoet aan de vereisten van vele hedendaagse bedrijven uit de distributie en lichte industrie, high-tech en dienstverlenende bedrijven. Flanders Expo en de groothandelsmarkt vormen interessante commerciële polen. Gent wordt tenslotte doorkruist door de E17autostrade die de centrale Oost-Vlaamse economische as vormt met KMO-zones erlangs.

Een realistische benadering van de economische potentialiteiten is dan ook aangewezen ${ }^{20}$. Gent heeft een uitstekende ligging ten opzichte van de driehoek Antwerpen, Brussel en Lille en de verbindingen zijn uitstekend. Het zeekanaal geeft een goede landinwaartse ligging maar een beperkte maritieme bereikbaarheid. De haven biedt goede mogelijkheden maar heeft ruimte en investeringen nodig. Er is een potentieel aan nieuwe technologieën door de aanwezigheid van de universiteit. Tenslotte biedt het stadsgewest een interessant grootstedelijk weefsel met eigen socio-economische aktiviteiten en snelle groei in de diensten. Dientengevolge kan Gent een eigen dynamiek behouden. Het kan een schakelfunctie vervullen tussen de drie metropolen en een aantal complementaire aktiviteiten aantrekken zonder daarom een satellietstad van Brussel te worden.

\section{Complementariteit tussen Brussel, Antwerpen en Gent binnen de context van de Vlaamse Ruit}

De complementariteit tussen Brussel, Antwerpen en Gent is niet zomaar eenduidig vast te leggen. Het is duidelijk dat Brussel als hoofdstad van België en Europa haar eigen funkties heeft, Antwerpen met de zeehaven heeft de hare. Zoals reeds aangegeven werd, dient Gent op een ander niveau geplaatst te worden. Dit niveauverschil kan aangetoond worden met de totale toegevoegde waarde van deze 3 stadsgewesten. Brussel nam in $199144 \%$ van de toegevoegde waarde, die gerealiseerd werd in Vlaanderen en Brussel-19, voor zijn rekening. Voor Antwerpenwas dit 17\% en voor Gent nog geen 5\%.

Er is zeker "woon-werk"-verkeer tussen Brussel en Antwerpen. Ook het vrachtvervoer tussen beide steden is een teken dat er duidelijk relaties bestaan. De luchthaven van Zaventem en Brucargo zijn eveneens bindende elementen voor economische relaties. Verder zijn er ook diverse zakenrelaties. Zo zijn Antwerpse bouw- en vastgoedmaatschappijen op de Brusselse markten actief, en Brusselse of internationale maatschappijen in Antwerpen. Toch valt hierbij op dat er een toenemende druk bestaat van Brussel op Antwerpen. Een aantal faktoren wijzen daarop:

- de ontwikkeling van een aantal kantoorcomplexen, ook op toplocaties met headquarter-functie, in Antwerpen,

- $\quad$ een aantal grote internationale hotelketens hebben of proberen een vaste stek te vinden in Antwerpen; mede door de druk op Brussel blijkt Antwerpen voldoende internationaal cliënteel te kunnen bieden,

- aantrekkingskracht van Antwerpen: door goedkopere huur in bedrijfsruimtes, maar ook voor particulieren is er een zekere overloop van Brussel naar Antwer-

20 D'hondt F. en T. Maes (1990); “Gent: Een stad vol plannen zonder realisaties, Een stad vol realisaties zonder planning,,, Planologisch nieuws, 10/4. 
pen.

Complementariteit bestaat mogelijks in de dienstverlening die in Antwerpen ondervertegenwoordigd is in vergelijking met Brussel. In Brussel daarentegen is de zakelijke dienstverlening sterk vertegenwoordigd, voornamelijk in de bank- en verzekeringsdiensten, boekhouding en fiscaliteit, informatica en reclame. Antwerpen wordt voor een aantal diensten vanuit Brussel bediend, eventueel met filialen in Antwerpen, maar dit genereert op zijn beurt weer inter-filiaal verkeer.

Tussen Antwerpen en Brussel (verreweg de twee grootste stadsgewesten in de Vlaamse Ruit) wordt er heel veel zakelijk verkeer gegenereerd. Bedrijven die hun produktie of distributie in Brussel hebben, kunnen mogelijks op Antwerpen aangewezen zijn voor de aanvoer van grondstoffen of de afvoer van produkten. Zelfs indien enkel administratieve en hoofdkwartierfuncties in Brussel plaats vinden en de produktie gedecentraliseerd is of de dienstverlening op verplaatsing wordt gerealiseerd, zal er nog steeds in belangrijke mate zakelijk verkeer worden gegenereerd tussen deze twee steden. Daarenboven liggen deze twee steden op de noord-zuid as tussen de Randstad en de Waalse driehoek: ook deze trafieken vergroten de interactie tussen deze twee steden.

Het stadsgewest Gent is economisch gezien verschillende keren kleiner dan Antwerpen, zoals reeds aangegeven is. Beide vormen samen met Zeebrugge de drie grote havensteden van Vlaanderen. De zeehaven van Gent is stukken kleiner dan die van Antwerpen en heeft haar eigen finaliteit. Alhoewel er wel degelijk sprake is van concurrentie tussen de drie havens, wordt die voor een stuk gedempt door het verschil in haveninfrastructuur en specialisaties. Daarenboven verschilt het hinterland van havens: Gent heeft een beperkte doorvoerfunctie via de Schelde en de Leie. Antwerpen heeft een betere verbinding met het hinterland via de binnenvaart en de belangrijkste eindbestemming van goederen die gelost worden in Antwerpen is de Ruhr-streek.

Gent en Antwerpen liggen op de belangrijke verkeersas Rotterdam-Parijs. Het stadsgewest Gent vervult tevens een belangrijke rol als het meest westelijk punt van de Vlaamse Ruit: met zijn uitgebreid aanbod aan universitair en niet-universitair hoger onderwijs en de universitaire laboratoria heeft het een functie als technologisch centrum en onderwijsstad. Dit heeft een direct effect op het westen van het land waar het bedrijfsleven veel gebruik makt van de beschikbare diensten in het stadsgewest.

Alhoewel deze beschrijving van de grootstedelijke gebieden in de Vlaamse Ruit heel summier is komt toch duidelijk naar voor dat (1) het economisch belang van Brussel en Antwerpen van een andere orde is dan deze van andere economische concentratiegebieden in Vlaanderen / België en dat (2) er een graad van differentiatie bestaat w.b. de economische structuur van deze drie grootstedelijke gebieden.

Grootstedelijke gebieden herbergen allerhande economische activiteiten die alleen kunnen gedijen binnen een gebied met een grootstedelijk draagvlak. De aanwezigheid van deze activiteiten is heel belangrijk voor de meeste bedrijven in de rest van Vlaanderen. Dit wordt 
het onderwerp van de volgende sectie. 


\section{De Vlaamse Ruit en zijn rol voor de economie in de rest van Vlaanderen}

\subsection{Inleiding}

In deze sectie bespreken we het belang van de Vlaamse Ruit voor de economie in de rest van Vlaanderen. In wat volgt vallen we vaak terug op het voorbeeld van Zuid West-Vlaanderen omdat de relatie tussen de economie in de Vlaamse Ruit en de streekeconomie al bestudeerd is in een andere studie ${ }^{21}$. Zuid West-Vlaanderen is een industriële pool die vooral gekenmerkt wordt door endogene groei en door een snelle inhaalbeweging inzake tertiarisering. Dit laatste is dan weer een direct gevolg van de kennisintensivering van de industriële activiteiten. In het volgend punt gaan we in op de vraag hoe productiegebonden diensten mede de competitiviteit bepalen van verschillende industriële activiteiten. In punt drie gaan we na wat de rol is van de Vlaamse Ruit in het versterken van de competitiviteit van industriële bedrijven in economische concentratiegebieden in de rest van Vlaanderen. Er wordt tevens nagegaan hoe economische meerwaarde kan gecreëerd worden door de interacties tussen de Vlaamse Ruit en de economische activiteiten in de rest van België.

\subsection{Productiegebonden diensten}

In tegenstelling met vele andere industriële regio's in Europa is een industriële regio als Zuid West-Vlaanderen er tot op heden in geslaagd om de industriële tewerkstelling te stabiliseren terwijl heel wat jobs in de tertiaire sector - via hulpdiensten en ondersteunende diensten - indirect bijdragen tot de locale industriële productie: De relatief goed gestructureerde industriële kern blijft de locale (groei in de) welvaart schragen.

Uit een reeks diepte-interviews met bedrijfsleiders blijkt dat het bedrijfseconomisch succes van industriële bedrijven naast industriespecifieke competenties vaak ook stoelt op competenties van hulpdiensten of ondersteunende diensten. M.a.w., het verwerven van een competitief voordeel in een industriële sector is vaak mee bepaald door de kwaliteit van de diensten waarop locale industriële diensten een beroep kunnen doen. Het aanbod en de bereikbaarheid van kwalitatief hoogstaande diensten is dus belangrijk voor het bestendigen van de competitiviteit in heel wat industrieën.

Het soort diensten dat hierbij bepalend is hangt af van sector tot sector, maar de volgende diensten komen frequent voor.

21 Vanhaverbeke W. (1994); Tertiarisering in een industriële regio: Een strategische visie op en beleidsprioriteiten voor Zuid West-Vlaanderen, Kortrijk: Charter 99, 185 p. 
Tabel 1: Belangrijke productie-gerelateerde diensten

\begin{tabular}{|c|c|}
\hline Dienst & Succesfactoren \\
\hline Toegepast technologisch onderzoek & $\begin{array}{ll}\text { - } & \text { Sectorspecifieke product- en procesinnovatie } \\
\text { - } & \text { Snelheid } \\
\text { - } & \text { Diffusie kennis }\end{array}$ \\
\hline Logistiek en transport & $\begin{array}{ll}\text { - } & \text { Snelheid } \\
\text { - } & \text { Flexibiliteit } \\
\text { - } & \text { Toepassingen IT }\end{array}$ \\
\hline Machinebouw en -onderhoud & $\begin{array}{ll}\text { - } & \text { Klantgerichtheid (maatwerk) } \\
\text { - } & \text { Snelle en frequente communicatie } \\
\text { - } & \text { Toepassingen nieuwe technologieën }\end{array}$ \\
\hline Onderwijs met technische oriëntatie & $\begin{array}{l}\text { - Vormen en bestendigen van "poule" van werkne- } \\
\text { mers die bedrijfs- en industrie-specifieke kennis } \\
\text { belichamen } \\
\text { - Gebruik nieuwe technologieën }\end{array}$ \\
\hline
\end{tabular}

Ook het strategisch omgaan (learning-by-doing) met nieuwsoortige informatiekanalen (zoals bijvoorbeeld video-conferencing, internet, multimedia, nieuwe commerciële diensten via telefoon of kabel, enz...) blijkt binnen heel wat industriële bedrijven uit te groeien tot een belangrijke succesfactor.

Er zijn natuurlijk ook andere diensten waarop de industriële bedrijven een beroep doen, maar dit zijn standaarddiensten waar geen concurrentieel voordeel uit te halen valt of ze zijn van marginaal belang voor de bedrijfsvoering (vb. industriële reiniging).

Heel wat van de diensten die vermeld worden in tabel 1 zijn niet allemaal locaal aanwezig. We vinden ze zelfs vaak niet terug in Vlaanderen of België. De groentenverwerkende nijverheid bijvoorbeeld, waarvan de productiehuizen geconcentreerd zijn in Zuid WestVlaanderen, doet om een aantal redenen beroep op Nederlandse machinebouwers en transporteurs. De meeste locale industriële bedrijven betrekken diensten vanuit andere landen en continenten; ze zoeken wereldwijd de kwalitatief beste diensten tegen de beste prijs. Voor gesofisticeerde producten zoekt men de know-how al vlug op mundiale schaal.

\subsection{De Vlaamse Ruit en locale infrastructurele voorzieningen in de rest van Vlaanderen}

Uit de vorige paragrafen is gebleken hoe de werking van de meeste industriële bedrijven ingebed is in de nationale en Europese economie. Slechts een kleine fractie van de toegeleverde goederen en diensten wordt betrokken uit de streek zelf. De meeste ervan worden verzorgd door andere Vlaamse / Belgische en internationale bedrijven.

In de volgende twee punten gaan we respectievelijk in op locale infrastructurele voorzieningen in de rest van Vlaanderen en de relatie die een economische pool buiten de Vlaamse 
Ruit kan uitbouwen t.o.v. de Vlaamse Ruit als een belangrijk en nabijgelegen stedelijke netwerk op internationaal niveau.

\subsubsection{Locale infrastructurele voorzieningen}

Welke infrastructurele voorzieningen kunnen locaal uitgebouwd worden in een economische pool buiten de Vlaamse Ruit? Hierbij dient men kritisch na te gaan welke competenties er beter betrokken worden uit andere economische en technologische centra en welke er best locaal uitgebouwd worden tot "centers of excellence".

Dit thema kan men uitwerken binnen het kader van de recente literatuur rond clusters en industriebeleid $^{22}$. Porter stelt een gestandaardiseerde methode voor om mogelijke clusters van bedrijfstakken samen te stellen. Binnen iedere cluster onderscheidt hij vier niveau's : Eindproducten, hulpstoffen, machines en dienstverlening. Het voordeel van deze benadering is dat het de klassieke indeling van de economie in industrie en diensten doorsnijdt. In plaats van de industrie onnodig te polariseren tegenover de diensten, toont hij aan hoe ze op elkaar aansluiten en elkaar versterken.

De clusterbenadering is belangrijk voor het economisch beleid omdat ze aangeeft dat er voor de verschillende clusters een verschillende geografische schaal geldt. Kusters en Minne $^{23}$ hebben voor Nederland verschillende bedrijfstakken gegroepeerd volgens de geografische schaal van de markten en de productienetwerken: Sommige productienetwerken zijn regionaal en hebben ook een beperkte geografische markt (bvb. de bouw). Snijbloemen worden op regionale schaal geproduceerd maar worden over de ganse wereld verkocht. Telecommuni-catieapparatuur en consumentenelektronica worden via global firms wereldwijd geproduceerd en verkocht.

Deze methodiek willen we verfijnen en ombouwen tot een analyse-instrument voor het economisch beleid. Jacobs en de Man $^{24}$ geven alvast interessante suggesties voor zo'n verfijning: Zij wijzen erop dat bedrijfsclusters in een regio de competitiviteit van de locale bedrijven kunnen verbeteren door het regionale netwerk van bedrijfscontacten te versterken en door terzelfdertijd zoveel mogelijk de aanwezige kennis in buitenlandse clusters te benutten.

Indien de geografische schaal niet alleen toegepast wordt op markten en productienetwerken maar ook op elk van de waardecreërende activiteiten in de waardeketen, krijgt men een beeld hoe de competitiviteit van een bepaalde bedrijfstak afhangt enerzijds van locale inputfactoren en anderzijds van competenties in andere bedrijfstakken buiten de regio.

22 Porter, M. (1990); The competitive advantage of nations, New York, Free Press.

Krugman, P. (1991); Geography and trade, Leuven University Press, Leuven en MIT-Press, Cambridge Mass.

23 Kusters, A. en B. Minne (1992); Technologie, marktstructuur en internationalisatie : de ontwikkeling van de industrie. Onderzoeksmemorandum nr. $90 \mathrm{CPB}$, Den Haag.

24 Jacobs, D. en A-P de Man (1995); “Clusters, industriebeleid en ondernemingsstrategie”, ESB 22-2-1995, pp. 172-177. 
In tabel 2 wordt dit geïllustreerd voor drie industrieën die sterk geconcentreerd zijn in Zuid West-Vlaanderen en getuigen van een sterke internationale competitiviteit. De geografische concentratie wijst op het feit dat de bedrijfseconomische competitiviteit ten dele stoelt op de locale economische situatie. Maar de locale economische omgeving kan slechts een deel van het succes verklaren : Zonder efficiënt gebruik te maken van economische competenties in andere regio's zou het internationaal succes van deze bedrijfstakken vlug verdwijnen.

Tabel 2: De origine van competitieve voordelen in drie industrieën

\begin{tabular}{|c|c|c|}
\hline \multicolumn{2}{|c|}{ Doorslaggevende factoren } & \multirow[t]{2}{*}{ Marginale factoren } \\
\hline Binnen de regio & Buiten de regio & \\
\hline \multicolumn{3}{|l|}{ Diepvriesgroenten industrie } \\
\hline $\begin{array}{l}\text { - Ondernemerscultuur } \\
\text { - Familiekapitaal } \\
\text { - Historisch toeval } \\
\text { - Kleine teeltoppervlakten in } \\
\text { West-Vlaanderen } \\
\text { - Nabijheid van sommige } \\
\text { landbouwproducten (bloemkool) } \\
\text { - Diepvriesinstallaties (service) }\end{array}$ & $\begin{array}{l}\text { - Machinebouwers Nederland } \\
\text { (technologisch geavanceerd) } \\
\text { - Gespecialiseerd transport Zuid- } \\
\text { Nederland } \\
\text { - Landbouwproducten : Land- } \\
\text { bouw in Nederland : toevoer via } \\
\text { havens }\end{array}$ & $\begin{array}{l}\text {-Teelttechnische kennisinfra- } \\
\text { structuur in de regio } \\
\text { - Regionale machinebouwers } \\
\text { (achterstand technologie) } \\
\text { - Hallen Roeselare } \\
\text { - Administratieve en financiële } \\
\text { diensten } \\
\text { - Computer en software }\end{array}$ \\
\hline \multicolumn{3}{|l|}{ Kunststofverwerkende industrie } \\
\hline $\begin{array}{l}\text { - Ondernemerscultuur } \\
\text { - Familiekapitaal } \\
\text { - Historisch toeval } \\
\text { - Klantgerichtheid / flexibele } \\
\text { automatisatie } \\
\text { - Sociaal klimaat } \\
\text { - Matrijzenbouwers (communica- } \\
\text { tie bij engineering, snelheid) } \\
\text { - Technologische ondersteuning } \\
\text { - Af- en bewerkingsactiviteiten } \\
\text { (communicatie; klantgerichtheid) }\end{array}$ & $\begin{array}{l}\text { - Grondstofleveranciers } \\
\text { - Machinebouwers } \\
\text { - Logistiek en warehousing } \\
\text { - Opleiding }\end{array}$ & $\begin{array}{l}\text { - Administratieve en financiële } \\
\text { diensten } \\
\text { - Computer en software } \\
\text { - Juridische diensten }\end{array}$ \\
\hline \multicolumn{3}{|l|}{ Textielsector } \\
\hline $\begin{array}{l}\text { - Ondernemerscultuur } \\
\text { - (Familiekapitaal) } \\
\text { - Geschoolde arbeid (vakman- } \\
\text { schap) } \\
\text { - Besturingssystemen (service) } \\
\text { - Electronisch gestuurde machines } \\
\text { - Bepaalde toeleveranciers } \\
\text { (spinnerijen) }\end{array}$ & $\begin{array}{l}\text { - CAD-CAM leveranciers } \\
\text { - Labo-apparatuur } \\
\text { - Mechanische machines } \\
\text { - Toeleveranciers standaard- } \\
\text { producten } \\
\text { - Productontwikkeling }\end{array}$ & $\begin{array}{l}\text { - Administratieve en financiële } \\
\text { diensten } \\
\text { - Juridische diensten } \\
\text { - Generieke hard- en software }\end{array}$ \\
\hline
\end{tabular}

Deze tabel leert ons heel wat over de kritische succesfactoren die de basis vormen van de internationale competitiviteit van geografisch geconcentreerde clusters van bedrijven: 
- Het eerste wat opvalt is de brede waaier van locale succesfactoren. Dit is deels het gevolg van de selectie: de drie sectoren vertonen een duidelijke geografische concentratie waardoor het belang van de locale factoren meer uitgesproken is dan in de meeste andere sectoren.

- Bij de locale factoren zijn er een aantal die telkens terugkeren : sociale verhoudingen, ondernemerschap, familiekapitaal, flexibiliteit, klantgerichtheid, snelheid. Dit wijst erop dat de competitiviteit in verschillende (clusters) van industrieën gebaseerd is op een aantal karakteristieken van de socio-economische omgeving. Een regionaal economisch beleid kan daarom niet alleen gericht zijn op clusters van bedrijfstakken: het moet integendeel onderzoeken hoe onderliggende deze karakteristieken van de socio-economische omgeving versterkt kunnen worden en hoe ze tot een hogere competitiviteit kunnen leiden in verschillende clusters van sectoren.

- Andere locale succesfactoren zijn dan weer specifiek voor een bepaalde bedrijfstak. In die zin dient het economisch beleid per sector na te gaan welke locale factoren en infrastructurele voorzieningen bijdragen tot het commercieel succes binnen deze sectoren. M.a.w., en kan geen zinvolle suggesties doen omtrent locale infrastructurele voorzieningen zonder eerst te zijn ingegaan op de specifieke werking van de verschillende sectoren.

- Verschillende belangrijke inputfactoren kunnen in principe zowel bij locale toeleveranciers als in andere regio's gekocht worden. Een mooi voorbeeld zijn de productiemachines voor de diepvriesgroentenindustrie: Er bestaan locale machinebouwers, maar buitenlandse machinebouwers krijgen steeds meer de voorkeur omwille van hun technologische voorsprong. Technologie gedreven concurrentie komt ook naar voor in de kunststofverwerkende industrie.

- Er zijn ook infrastructurele voorzieningen die niet bepalend zijn voor het commercieel succes van bedrijven in deze sectoren. Het economisch beleid dient kritisch te staan tegenover bestaande locale infrastructurele voorzieningen, want die zijn niet allemaal relevant voor de competitiviteit van de bedrijven.

- Uit de lijst van streekgebonden succesfactoren blijkt dat de rol van de kenniseconomie steeds belangrijker wordt. De competentie binnen de kunststofverwerkende industrie is voor een stuk bepaald door de snelheid waarmee bedrijven kennis kunnen uitwisselen in de engineering-fase. De textielsector en grote bedrijven als Bekaert dringen aan op het verbeteren van de opleidingen zodat de "poule" van industrie-specifieke technologische know-how vernieuwd kan worden.

Kortom, de concurrentiële positie van bedrijven in de rest van Vlaanderen wordt bepaald door een combinatie van locale competenties en competenties die betrokken worden uit andere regio's. De competitiviteit van de meeste bedrijven wordt bepaald door het aantrekken van verschillende competenties uit diverse regio's in combinatie met de economische troeven van de eigen regio. In principe kan voor iedere waardecreërende activiteit in de 
waardeketen competenties uit een andere regio aangetrokken worden.

\subsubsection{Een illustratie: Kennis als "resource"}

Kennis en creativiteit zijn uitgegroeid tot de belangrijkste vorm van "kapitaal" binnen de rijke "industrielanden". Kennis, technologische know-how en human capital verschillen evenwel fundamenteel van klassieke inputfactoren zoals arbeid en kapitaal. Deze laatste zijn gegevenheden: ongeschoolde arbeid is steeds beschikbaar en kapitaal is tegenwoordig wereldwijd beschikbaar via de internationale kapitaalmarkt. Kennis, technologische knowhow en human capital daarentegen zijn nooit zomaar beschikbaar. Ze moeten altijd ontwikkeld en verbeterd worden en daarvoor is er een solide maatschappelijke kennis- en opleidingsinfrastructuur nodig.

Dit verschil heeft belangrijke implicaties voor de relatie tussen het bedrijfsleven en de overheid. Bedrijven worden voor hun werking steeds meer afhankelijk van hun economische en maatschappelijke omgeving voor het realiseren van competitieve voordelen. Bedrijven die intens gebruik maken van kennis en creativiteit zijn voor een goeie werking afhankelijk van de competitiviteit van andere bedrijven, de aanwezigheid van universiteiten en onderzoekslaboratoria en overheidsdiensten. M.a.w., de competitiviteit van bedrijven die strategisch gebruik maken van informatie en kennis is intens verweven met de aanwezige opleidings- en kennisinfrastructuur in de ruime economische omgeving. Als gevolg hiervan heeft de bedrijfswereld er alle belang bij om te ijveren (lobbyen) voor een adequate kennis- en opleidingsinfrastructuur ${ }^{25}$. "Adequaat" betekent hier dat er onophoudelijk een afweging moet worden gemaakt tussen het betrekken van informatie, technologie en human capital uit andere regio's en landen enerzijds en het uitbouwen van competenties via locale infrastructurele voorzieningen anderzijds. Vraag is nu welke locale infrastructurele voorzieningen er dienen uitgebouwd te worden en welke competenties moeten betrokken worden uit andere regio's en landen.

Om op die vraag te antwoorden kan gebruik gemaakt worden van recente literatuur omtrent dit thema ${ }^{26}$. De conclusies ervan kan men als volgt samenvatten:

- Locale en regionale kennis- en opleidingsinfrastructuur zijn belangrijk in de ontwikkeling

25 Camagni, R. (1991); Space, networks and technical change: An evolutionary approach. In R. Camagni (ed.), Innovation networks, Belhaven Press, London.

Justman, M. en M. Teubal (1995); “Technological infrastructure policy (TIP): creating capabilities and building markets", Research Policy, 24, pp. 259-281.

Tassey G. (1992); Technology infrastructure and competitive position, Kluwer Academic Publishers.

26 Rodwin, L. en H. Sazanami (eds.) (1989); Deindustrialization and regional economic transformation The experiences of the United States. Unwin Hyman, Boston.

Tödtling F. (1994); The uneven landscape of innovation poles - Local embeddedness and global networks. In: A. Amin en N. Thrifts (eds.), European Regions: Their place in the Global Economy, Oxford University Press, Oxford.

Tödtling F. (1994); "Regional networks of high technology firms - the case of the Greater Boston region", Technovation, 14 (5), pp. 323-243. 
en bestendiging van de competitieve voordelen van bedrijven met een locale aanwezigheid.

- Het belang van deze infrastructurele voorzieningen verschilt van sector tot sector omdat ook de succesfactoren sectorspecifiek zijn.

- De infrastructurele noden binnen een bepaalde sector evolueren naargelang de levenscyclus van de sector. Deze infrastructurele voorzieningen zijn vooral bepalend in de vroege groeifase van een sector maar ook in een matuur stadium kunnen infrastructurele voorzieningen een belangrijke rol spelen.

- Het competitief voordeel in heel wat sectoren berust op heel specifieke factoren die slechts beschikbaar zijn in bepaalde regio's. Deze factoren zijn enkel locaal aanwezig omdat ze het resultaat zijn van een unieke socio-economische evolutie. In die zin kunnen sterke geografische concentraties in bepaalde sectoren ontstaan.

Deze conclusies geven enkele aanwijzingen voor een antwoord op de hierboven gestelde vraag. Een onderzoek naar locale infrastructurele voorzieningen dient te starten vanuit de specifieke noden van bedrijven met een locale aanwezigheid. Men gaat nog teveel uit van de gedachte dat het aanbod van infrastructurele voorzieningen voldoende is om de economische slagkracht van een regio te dynamiseren.

Eens men de specifieke noden van de bedrijven kent dient men na te gaan of de nodige infrastructurele voorzieningen niet in een grootstedelijk gebied zoals de Vlaamse Ruit gesitueerd moeten zijn. Deze die een grootstedelijk gebied als basis behoeven dienen daar gelocaliseerd te worden. Voorbeelden zijn universiteiten, hogescholen met een generieke opleiding, research laboratoria (bvb. met betrekking tot nieuwe technologieën), congres- en expositiecentra met een internationale reputatie, internationale luchthavens, enz... Infrastructurele voorzieningen die in een kleinstedelijk gebied zouden kunnen gevestigd worden, dienen niet automatisch gelocaliseerd te worden in de eigen streek. Wanneer blijkt dat de bedrijven uit andere regio's en landen een uitstekende dienstverlening kunnen verkrijgen, zou een duplicatie van deze infrastructurele ondersteuning in eigen streek zonde zijn.

Heel wat gespecialiseerde inputs kan men evenwel niet betrekken uit andere regio's. Daar zijn verschillende redenen voor. Technisch geschoolde arbeidskrachten bijvoorbeeld dient men in hoofdzaak locaal op te leiden en bij te scholen omdat arbeid een weinig mobiele factor is. Kennisoverdracht van toegepaste technologische know-how bijvoorbeeld is vaak moeilijk (tacit knowledge) omdat er intensief en frequent menselijk contact nodig is om de kennis te transfereren. Dit is niet mogelijk als de afstanden te groot zijn.

Er zijn dus een aantal infrastructurele voorzieningen met een strategisch economische rol die locaal kunnen uitgebouwd worden. Toch dient men hierbij voorzichtig te werk te gaan: Men dient enkel die kennis- en opleidingsinfrastructuur uit te bouwen waar de streek een voortrekkersrol kan spelen: Dit houdt in dat de groep van bedrijven die er gebruik van maken een kritische grootte heeft en dat deze bedrijven concurrentieel zijn op internationaal vlak. Dit zijn voorwaarden om te voldoen aan de local-for-global-strategie.

Deze bovenlocale functie van economisch ondersteunende infrastructurele voorzieningen in 
een bepaalde streek houdt in dat alleen de sterk presterende clusters van sectoren voor dergelijke locale infrastructurele voorzieningen in aanmerking komen. Deze infrastructurele ondersteuning zal bijgevolg ook een specialistisch en een sectorspecifiek karakter hebben.

Een voorbeeld : Een Researchpark in Zuid West-Vlaanderen heeft enkel zin als het een ondersteunende functie kan vervullen t.o.v. belangrijke clusters van sterk presterende sectoren. In de streek zijn er geen hoogtechnologische sectoren of clusters van sectoren enkele grote bedrijven niet te na gesproken - maar er zijn heel wat traditioneel sterke sectoren die aan kennisintensivering toe zijn. Een voorbeeld is de kunststofverwerkende industrie die - net zoals dat het geval is in veel andere industrieën - steeds meer een kennisintensieve sector aan het worden is ${ }^{27}$. Een locaal researchpark kan helpen om bedrijven de nodige know-how te laten ontwikkelen als de technologie moeilijk te vinden is of moeilijk transfereerbaar is vanuit andere regio's. Daarenboven moet het gaan om echt toegepast onderzoek dat perfect aansluit bij de noden van de locale productiehuizen. De competitiviteit van de kunststofverwerkende bedrijven in Zuid West-Vlaanderen zou bvb. verbeterd kunnen worden door technologie-ondersteuning via een technologiecentrum. Zo'n centrum dient zo dicht mogelijk gelocaliseerd te worden bij de productiecentra omdat de communicatie tussen de bedrijven en het centrum intens en complex van aard is. Dergelijke communicatie kan men immers moeilijk via telecommunicatieapparatuur doorsturen.

Wat is nu de rol van een nabijgelegen stedelijk netwerk op internationaal niveau voor deze bedrijven? Op deze vraag proberen we een antwoord te formuleren in de volgende sectie.

\subsubsection{Strategie t.o.v. de Vlaamse Ruit}

De Vlaamse Ruit is het grootste economische concentratiegebied in Vlaanderen en heeft een niet geringe "aantrekkingskracht" op de andere economische polen in Vlaanderen. Gegeven de groeiende internationalisatie van de economie en het groeiend belang van stedelijke netwerken met internationale uitstraling zal deze invloed ongetwijfeld nog toenemen in de toekomst.

Het statuut van de Vlaamse Ruit als stedelijk netwerk op internationaal niveau zal dus zonder twijfel een geografische concentratie van de moderne economische infrastructuur met zich meebrengen en economische polen buiten de Vlaamse Ruit zullen steeds meer economische activiteiten moeten betrekken uit de Ruit.

In essentie dient men in gebieden buiten de Vlaamse Ruit de actieve uitbouw van dit grootstedelijk netwerk als een positief gegeven te beschouwen. Zonder een goed functionerende Vlaamse Ruit zouden bedrijven deze diensten moeten betrekken uit grootstedelijke gebieden die heel wat verder liggen waardoor de dienstverlening minder efficiënt, duurder of zelfs onmogelijk wordt.

27

Yinnon, A.T. (1996); “The shift to knowledge-intensive production in the plastics-processing industry and its implications for infrastructure development: three case studies: New York State, England and Israel", Research Policy, 25, pp. 163-179. 
De vraag stelt zich meteen hoe het gebied buiten de Vlaamse Ruit het best kan inspelen op de infrastructuur binnen de Ruit. Het gaat immers niet op om op gewestelijk vlak de economische infrastructuur te concentreren binnen de centrale ruit zonder de toegang ertoe vanuit de rest van Vlaanderen te optimaliseren. In die zin dient binnen het perspectief van het Ruimtelijk Structuurplan Vlaanderen dringend werk gemaakt te worden van het goederen-, personen- en informatieverkeer tussen de Vlaamse Ruit en de rest van Vlaanderen. Deze eis voor een betere toegang tot de infrastructuur in de Vlaamse Ruit houdt ook in dat locale infrastructurele voorzieningen buiten de Vlaamse Ruit complementair zijn met die binnen de Ruit.

Maar infrastructurele eisen zijn niet voldoende. Bedrijven kunnen alleen optimaal gebruik maken van de infrastructuur binnen de Vlaamse Ruit door netwerkfuncties met de ruit en andere techno-economische centra van belang uit te bouwen, waardoor de economische competenties binnen de subregio kunnen behouden of versterkt worden. In die zin is het van groot belang dat de bedrijven efficiënt en strategisch leren omgaan met de informatie en diensten die voorhanden is in grote techno-economische centra. Dit kan alleen door het opzetten van (inter)nationale functionele netwerken: deze netwerken vormen steeds meer mee de basis van de hedendaagse competitiviteit in industriële (ook traditionele) sectoren. In andere landen is men daarin al verder ${ }^{28}$. Netwerkvorming kan niet gebeuren op basis van individuele inspanningen, maar kan alleen ontstaan op basis van gezamelijke inspanningen van de bedrijven in een regio.

\section{Besluit}

Vlaanderen heeft slechts een paar economische troeven om op duurzame wijze economische welvaart te genereren. Een eerste heeft betrekking op de processen om producten of diensten bij de consument te brengen ongeacht waar ze geproduceerd zijn. In een industrieland is de bevolking koopkrachtig wat heel wat jobs verzekert in de logistiek, de marketing en de distributie, de kleinhandel, horeca, transport en persoonlijke dienstverlening. Voor België vormt de centrale geografische ligging binnen de Europese Unie nog een extra troef. Een tweede strategie heeft betrekking op de vraag hoe rijke industrielanden op een duurzame wijze goederen en diensten kunnen produceren. Industrielanden dienen te concurreren op basis van het hoge kennisniveau van de actieve bevolking. Kennis is immers de enige ressource die niet zomaar te verplaatsen is naar NILs of ontwikkelingslanden; Het bereiken van een hoog gemiddeld opleidingsniveau is een werk van lange adem, zodat kennis een duurzame bron van welvaart en competitieve voordelen kan zijn.

Het regionaal economisch beleid dient zich te richten op de infrastructurele vereisten voor het realiseren van deze twee troeven. Door de verscherpte internationale concurrentie staan 
regio's binnen de geïndustrialiseerde landen in onderlinge concurrentie en bedrijven zullen hun waarde-activiteiten ten dele localiseren in functie van de economische en technologische attractiviteit van deze regio's.

Om economisch attractief te zijn dient het regionaal economisch beleid gelijktijdig te waken over twee doelstellingen. Enerzijds dient het ervoor te zorgen dat bedrijven in de regio gemakkelijk toegang krijgen tot de (productie)factoren in andere regio's en landen. Anderzijds dient het beleid na te gaan welke infrastructurele voorzieningen locaal moeten uitgebouwd worden. Locale voorzieningen kunnen evenwel niet langer alleen een locaal belang hebben: wanneer de voorziening betrekking heeft op sectoren waarin bedrijven Europees of wereldwijd concurreren dan moeten de voorzieningen uitgroeien tot centers of excellence waarvoor ook buitenlandse bedrijven bereid zijn te betalen voor de aangeboden diensten.

Het economisch belang van een grootstedelijk netwerk met internationale uitstraling kan binnen deze schets van de opkomst van de kenniseconomie moeilijk onderschat worden. De Vlaamse Ruit is ongetwijfeld in potentie een grootstedelijk netwerk met internationale uitstraling. De Ruit heeft alle economische karakteristieken die wijzen op zo'n grootstedelijk netwerk. Terzelfdertijd constateren we een erosie van haar economische slagkracht in de periode 1981-1991. Dit wijst op een aantal problemen die ondermeer beleidsmatig moeten opgelost worden indien de Vlaamse Ruit haar internationale rol als netwerk wil waarmaken. Voorbeelden zijn het gebrek aan overheidsinvesteringen in infrastructuur; verkeerscongestie gekoppeld aan een mank lopend openbaar vervoer; gebrek aan ruimte voor economische activiteiten binnen grootstedelijke gebieden; verval van binnensteden en dalende tewerkstelling in de horeca aldaar; enz... In die zin moet er een trendbreuk gerealiseerd worden opdat de Vlaamse Ruit haar economische rol zou kunnen vervullen.

Binnen de Vlaamse Ruit spelen de drie stedelijke gebieden de belangrijkste rol. Brussel, Antwerpen en Gent vervullen hoofdzakelijk een complementaire economische rol en de onderlinge afhankelijkheid van de drie grootstedelijke gebieden is groot.

Ook t.o.v. voor de economie in de rest van Vlaanderen speelt de Vlaamse Ruit een belangrijke rol. De meeste bedrijven zijn ingebed in de nationale en Europese economie en slechts een kleine fractie van de toegeleverde goederen en diensten wordt betrokken uit de streek zelf. De competitiviteit van de meeste bedrijven wordt bepaald door het aantrekken van verschillende competenties uit diverse regio's in combinatie met de economische troeven van de eigen regio. Men kan de Vlaamse Ruit beschouwen als de poort voor de rest van Vlaanderen op de belangrijkste economische concentratiegebieden in Europa. De economische meerwaarde die gegenereerd wordt door de nabijheid van een grootstedelijk netwerk met internationale uitstraling kan moeilijk onderschat worden. De keerzijde van de medaille is dat verschillende grootstedelijke netwerken concurreren met elkaar voor het aantrekken van economische activiteiten. Om die attractiviteit te behouden en te versterken dient er continue geïnvesteerd te worden in de infrastructurele voorzieningen binnen de Vlaamse Ruit.

In essentie dient men dus in gebieden buiten de Vlaamse Ruit de actieve uitbouw van dit 
grootstedelijk netwerk als een positief gegeven te beschouwen. De rest van Vlaanderen profiteert van de Vlaamse Ruit doordat een ruimer waaier van economische activiteiten en dienstverlening binnen een straal van $100 \mathrm{~km}$ ligt. Zonder een goed functionerende Vlaamse Ruit zouden bedrijven deze diensten moeten betrekken uit grootstedelijke gebieden die heel wat verder liggen waardoor de dienstverlening minder efficiënt, duurder of zelfs onmogelijk wordt.

Een economische pool buiten de Vlaamse Ruit kan maar inspelen op de infrastructuur binnen de Ruit wanneer gezorgd wordt voor een optimale interactie tussen de Vlaamse Ruit en de rest van Vlaanderen. In die zin dient men werk te maken van het goederen-, personenen informatieverkeer tussen de Vlaamse Ruit en de rest van Vlaanderen. Deze eis voor een betere toegang tot infrastructurele voorzieningen in de Vlaamse Ruit houdt ook in dat locale infrastructurele voorzieningen buiten de Vlaamse Ruit complementair zijn met die binnen de Ruit. 